\title{
Peranan Letnan I Nawawi Manaf Di Bengkulu Pada Masa Revolusi Fisik Tahun 1945-1949
}

\author{
Amatullah Fauziah, Syafrudin Yusuf, Alian \\ Program Studi Pendidikan Sejarah, Fakultas Keguruan dan Ilmu Pendidikan, Universitas Sriwijaya
}

\section{Abstrak}

Revolusi fisik terjadi dari tahun 1945-1950, berawal dari ketidak inginan bangsa asing untuk melepaskan Indonesia. Meskipun Indonesia telah merdeka, tetapi bangsa asing tetap ingin menguasai kembali. Salah satunya Bengkulu, yang memiliki sumber daya alam yang melimpah seperti tambang emas dan lainnya. Bengkulu juga mempunyai tokoh pemuda yang sangat membela kemerdekaan Indonesia di tanah Bengkulu. Nawawi Manaf merupakan tokoh pejuang kemerdekaan. Semangat dalam mempertahankan kemerdekaan dan anti penjajah membuatnya terus melawan penjajah. Hingga Nawawi Manaf diberi amanah untuk memimpin berbagai organisasi kemerdekaan. Permasalahan yang dibahas adalah bagaimana peran letnan I Nawawi Nanaf pada masa awal kemerdekaan Indonesia, dan masa agresi militer Belanda I dan II di Bengkulu. Tujuan penelitian ini adalah untuk mengungkap peran Letnan I Nawawi Nanaf dalam mempertahankan Kemerdekaan Indonesia di Bengkulu. Metode penulisan yang digunakan adalah metode Historis, dengan menggunakan lengkah-langkah heuristik, kritik sumber, interpretasi, dan historiografi. Hasil penelitian menunjukkan bahwa secara menyeluruh perjuangan Nawawi Manaf di awal kemerdekaan dilakukan dengan berbagai cara, untuk meyakinkan bahwa Indonesia telah merdeka di tanah Bengkulu. Letnan I Nawawi Nanaf berperan dalam perjuangan melawan perang Agresi Militer Belanda I \& II di Bengkulu dan memimpin berbagai petempuran sebagai komandan Batalyon XXVI.

\section{Kata Kunci: Revolusi Fisik, Bengkulu, Nawawi Manaf}

\section{Pendahuluan}

Kemerdekaan Indonesia tidak terlepas dari do`a dan usaha para pejuang dalam merebut Kemerdekaan Indonesia dari para penjajah bangsa asing. Para pejuang kemerdekaan tersebar dari berbagai daerah di Indonesia dan semua elemen masyarakat pun terlibat. Seperti tentara, masyarakat sipil, tokoh masyarakat, dan tokoh agama yang saling bersatu dalam memperjuangkan kemerdekaan. Berita akan kemerdekaan Indonesia disambut meriah dari berbagai daerah di Indonesia. Proklamasi kemerdekaan juga dirasakan di Keresidenan Bengkulu. Kabar yang diterima mengenai Indonesia telah merdeka sedikit lambat. Oleh karena di Bengkulu masih banyak tentara Jepang yang menyembunyikan kabar kemerdekaan. Akhir Agustus 1945, Bengkulu baru menerima jika Indonesia telah merdeka yang dibawa oleh Buldani Masik di Manna. Namun berita tersebut belum dapat dipastikan kebenarannya. Tanggal 3 September 1945, baru berita proklamasi di terima di daerah Bengkulu melalui surat kabar Palembang Simbun. Berita tersebut akhirnya tersebar di berbagai daerah di Bengkulu (Tim Peneliti Sejarah Revolusi Kemerdekaan). Kemerdekaan Indonesia sebagai tonggak awal lahirnya Indonesia baru yang bebas dari penjajah. Akan tetapi, setelah merdeka 
para penjajah belum mengikhlaskan Indonesia sepenuhnya. Penjajah masih berusaha untuk kembali ke Indonesia. Perjuangan masyarakat ternyata belum dikatakan selesai. Dalam mempertahankan kemerdekaan, kemudian terjadi perlawanan dengan bangsa asing yang dinamakan revolusi fisik. Revolusi fisik terjadi tahun 1945-1950.

Dalam peristiwa tersebut terdapat perjuangan fisik dengan pertempuran atau gencatan senjata dan non fisik dengan diplomasi. Revolusi fisik yang terjadi di Bengkulu tidak jauh berbeda dengan daerah lainnya. Meskipun kemerdekaan telah berkumandang, tetapi tentara Jepang masih tidak rela Bengkulu dikuasai sepenuhnya. Jepang masih menguasai pemerintahan. Ditambah dengan masyarakat yang masih banyak berpihak dengan tentara Jepang.

Kondisi tersebut membuat antekantek Jepang masih berdiri kokoh di Bengkulu. Bengkulu yang merupakan salah satu keresidenan, sudah ada sejak zaman penjajahan Belanda, dengan status daerah administrasi di bawah koordinasi Gubernur Sumatera. Status tersebut sampai berlanjut di zaman penjajahan Jepang. Bengkulu sendiri masuk dalam Sumatera bagian Selatan. Daerah Bengkulu yang memiliki kekayaan sumber daya alam dan mineral dari hasil tambang, seperti batubara dan emas. Bengkulu juga memiliki kekayaan laut, serta hutan yang subur. Kekayaan dan wilayah yang strategis tersebut menjadi daya tarik bagi bangsa asing (Belanda) untuk dapat menguasai Bengkulu kembali. Belanda melakukan Agresi Militer Belanda I tahun 1947 dan Agresi Militer Belanda II tahun 1949. Peristiwa tersebut membuat keadaan semakin sulit dengan ditambah para pejuang yang gugur di medan perang. Pemuda Bengkulu yang anti penjajah, berupaya mengusir penjajah. Salah satunya tokoh pemudanya adalah Nawawi Manaf.

Pemuda Bengkulu yang memiliki jiwa semangat untuk melawan penjajah. Nawawi Manaf memiliki strategi yang baik dalam diplomasi. Perjuangan Nawawi Manaf dalam Masa Revolusi di Bengkulu sangat berarti. Dari strategi yang dipakai dan kemampuan dalam memimpin pasukan. Oleh sebab prestasi dan kegigihan dalam mempertahankan kemerdekaan. Selayaknya menjadi pahlawan nasional dari Bengkulu. Selain sebagai inspirasi dalam penguatan identitas dan jati diri bangsa (Susanti, Joebagio, \& Yamtinah, 2018)

Nawawi Manaf adalah putra daerah Bengkulu yang memiliki semangat juang dalam membela kemerdekaan yang anti penjajah. Prestasi dan strateginya membuat Nawawi Manaf menjadi salah satu pejuang Bengkulu yang mengharumkan nama Indonesia. Tujuan penulisan ini adalah untuk mengidentifikasi peran letnan I Nawawi Nanaf pada awal kemerdekaan Indonesia, dan masa agresi militer Belanda I \& II di daerah Bengkulu. 


\section{Tinjauan Pustaka}

\section{A. Keadaan Umum Bengkulu}

\section{Geografis Bengkulu}

Wilayah Bengkulu secara astronomis terletak di sekitar titik koordinat 2018'-4030' dan 1010-1030 BT. Luasnya sekitar $19.831 \mathrm{~km}^{2}$ terdiri dari $19.213 \mathrm{~km}^{2}$, tanah daratan dan $600 \mathrm{~km}^{2}$ danau dan rawa, sedangkan luas perairan pantai $9.000 \mathrm{~km}^{2}$ dengan panjang pantai $500 \mathrm{~km}^{2}$ (Purwanti, 2013). Bengkulu memiliki iklim tropis. Secara regional, daerah Bengkulu terletak di dalam zona Indo-Australia yang bercirikan suhu, kelembapan, dan curah hujan yang tinggi. Walaupun curah hujan bulanan beragam secara musiman, dan menjadikan terbentuknya musim hujan dan musim kemarau.

Iklim yang ada di Bengkulu berupa musim hujan berlangsung lebih kurang dari bulan November-April dan musim kemarau terjadi pada bulan Juli-September. Daerah Bengkulu di bagian barat merupakan daratan rendah, sedangkan di bagian timur terdapat bukit barisan yang memanjang dari barat laut-tenggara yang dilihat dari keadaan topologi daerah Bengkulu. Bengkulu memiliki beberapa pulau antara lain Pulau Enggano, Pulau Mega dan Pulau Tikus yang terletak di sebelah selatan. Wilayah Bengkulu memanjang dari barat laut-tenggara. Bengkulu memiliki gunung tertinggi. Gunung tersebut adalah Gunung Hulu Polik dengan ketinggian 2.493 m DPI, disusul dengan Gunung Sebelat dengan ketinggian 2.383 m DPI, Gunung Bukit Kaba dengan ketinggian 1936 m DPI dan Gunung Bungkuk. Sungai besar yang melintasi, antara lain Sungai Selagan, Ipuh, Sebelat, Serangai, Ketahun, Bengkulu, Lais, Alas, Nasal dan Sambat. Aliran sungai di daerah Bengkulu mencaai 117 aliran.

Terdapat tiga sungai yang terbesar yang dapat dilayari oleh kapal berbobot 25 ton. Sungai tersebut ialah Sungai Ketahun, Sungai Mular dan Sungai Selagan teretak di Kecapatan Ketahun Muko-Muko Selatan, dan Muko-Muko Utara. Bagian selatan Provinsi Bengkulu terdapat hutan heterogen dengan berbagai tanaman dan jenis kayu. Misalnya, kayu rasak, merbau, rasamala, medang, dan meranti. Keadaan tanah Bengkulu berumur kuarter, tersier dan sedimen tersier. Di bagian Bengkulu Utara terdiri dari tanah yang biasa disebut tanah marginal.

Tanah jenis ini tidak baik untuk digunakan sebagai lahan tanaman pangan. Akan tetapi bila mengolah tanah ini dengan teknik pertanian pengolahan tanah, maka dapat digunakan dengan baik. Bukan hanya tanah marginal, Bengkulu juga memiliki tanah yang kurang subur. Tanah tersebut ialah jenis Ultisol dan Oksisol. Bengkulu dipenuhi oleh pegunungan barisan. Secara morfologi daerah Bengkulu terbagi menjadi lima bagian, antara lain: daratan rendah, perbukitan bergelombang, daratan tinggi, pengunungan dan kerucut gunung api. 
Wilayah Bengkulu bagian barat terdiri atas perbukitan rendah landau. Wilayah yang bergelombang telah dikembangkan sejak kedatangan transmigran. Pada bagian tengah Bengkulu merupakan daerah pegunungan kasar. Untuk mencapainya sulit, sebab secara topologi cukup terjal. Bagian timur terdiri dari perbukitan menggelombang dan daratan rendah serta rawa. Daratan rendah meliputi sekitar 15\% daerah yang dipetakan. Tersebar di sekitar sungai Megang, sungai Klingi dan sepanjang sungai Kikim. Daratan tinggi terdapat di sekitar zona Sesar Sumatera. Di tenggara pegunungan Gumai yaitu daratan tinggi Pasemah.

Pegunungan bertimbun kasar dengan lereng curam yang terletak di bagian tengah lembah. Ke arah barat laut tenggara dengan ketinggian antara 5001.700 di atas permukaan laut. Bengkulu memiliki kekayaan yang melimpah. Terbukti adanya flora dan fauna yang tersebar di berbagai daerah. Sebab memiliki hutan heterogen yang lebat. Jenis floranya, antara lain kayu. Seperti kayu rasak, merbau, rasamala, medang, meranti, trembesi dan ketuko.

Hasil hutan yang menjadi komoditi daerah, antara lain rotan, demar, biga dan kasiavera. Kemudian tanaman yang dibudidayakan, seperti kayu manis, karet, kelapa sawit, teh, kopi, tembakau, kelapa, cengkih dan sayur-sayuran. Fauna di Bengkulu memiliki satwa liar yang masa sekarang sulit dijumpai. Binatang liar tersebut antara lain, badak, gajah, harimau sumatera serta beruang. Terdapat pula jenis burung kuao dan gagak. Jenis ikan yang dijumpai di Bengkulu ialah ikan gagu, ikan pari, ikan kakap merah, rajuangan, udang dan jenis hewan laut lain. Sumber daya mineral dan energi di daerah Bengkulu terdari dari emas, perak, minyak bumi, batubara dan bebatuan.

Lapisan batubara potensial terdapat di Air Kotok (Kabupaten Bengkulu Utara), di bagian utara Desa Tanjung Alam (Kabupaten Rejeng Lebong), di bagian timur Bengkulu dari dara eksplorasi dari perusahaan swasta menunjukkan bahwa, daerah tersebut mengandung lebih dari 5.000.000 ton cadangan batubara dengan luas $804.779 \mathrm{~m}^{2}$ dan tebal masing-masing lapisan antara 0,8-6,0 m.

Bengkulu juga kaya bebatuan yang berasal dari gunung api andesir dan basal. Bebatuan ini untuk pembangunan. Selain itu juga mempunyai kekayaan beragam, dari flora, fauna, mineral dan energi. Sehingga membuat mata pencarian warga Bengkulu beragam. Mulai nelayan, petani, peternak, penambang, pertukangan dan pengrajin seni.

\section{Demografis Bengkulu}

Penduduk asli Bengkulu terlahir dari dua kelompok besar. Pertama, kelompok besar pribumi yang terdiri dari empat keluarga besar, antara lain keluarga besar Sungai Lemau, keluarga besar Sungai 
Hitan, keluarga besar Sillembar dan keluarga besar Muko-Muko. Kedua kelompok pribumi keturunan Bugis dan Madura. Kelompok besar pribumi terbentuk dari berbagai suku dan marga. Suku yang ada di Bengkulu terdiri dari suku bangsa Melayu, suku bangsa Rejang, suku bangsa Serawai, suku bangsa Lembak, suku bangsa Muko-Muko, suku bangsa Pekal, suku bangsa Kaur, suku bangsa Pasemah dan suku bangsa Enggano. Kehidupan sosial masyarakat Bengkulu sangat menjunjung tinggi adat istiadat. Hal ini tergambar dari sistem perkawinan dan sistem hak waris.

\section{Keresidenan Bengkulu}

Bengkulu merupakan sebuah keresidenan yang sudah ada sejak zaman penjajahan Belanda. Dengan status daerah administrasi di bawah koordinasi Gubernur Sumatera. Status tersebut berlanjut sampai zaman penjajahan Jepang. Setelah Indonesia merdeka dengan terbentuknya sub provinsi Sumatera Selatan, pada bulan Mei 1946 berdasarkan Undang-Undang Nomor 1 tahun 1945 untuk pertama kali keresidenan Bengkulu dibawah koordinasi Palembang. Berdasarkan Undang-Undang Nomor 10 dan 22 tahun 1948, tentang pembagian Provinsi Sumatera menjadi tiga bagian, yaitu Provinsi Sumatera Utara, Provinsi Sumatera Tengah dan Provinsi Sumatera Selatan. Wilayah Bengkulu yang statusnya masih dalam keresidenan tergabung dalam Provinsi Sumatera Selatan.

\section{B. Keadaan Bengkulu sebelum \\ Proklamasi}

\section{Masa Belanda}

Pada masa pemerintahan Belanda, rakyat merasa tertekan. Sebab mereka melakukan perombakan semua aturan terdahulu. Kemarahan rakyat akhirnya memuncak dengan perlawanan yang menyebabkan Residen Knoele terbunuh pada 1833. Di susul dengan penghancuran tentara Belanda oleh rakyat di daerah dekat Dusun Tertik. Tatkala mereka sedang dalam perjalanan mengantarkan bekal makanan dan minuman ke pos Belanda di Dusun Keban.

Belanda melakukan penghapusan kedudukan raja dan penguasa Bengkulu. Terbukti pada 1861 Pangeran Mohamad Syah II dari Sungai Lemau diberhentikan dengan satu keputusan pemerintahan jajahan Belanda. Di susul pada tahun 1862 terhadap Pangeran bangsa Negara dari Sungai Hitam. Dengan Pangeran Nata Diraja dari Silebar pada tahun 1864 dan pada tahun 1870 dengan Sultan Takdir Khalifatullahsyah dari Muko-Muko.

Dengan penghapusan kedudukan para raja, maka rakyat tidak diam saja. Mereka menghormati dan menjunjung tinggi raja. Dengan berbagai cara dilakukan untuk membela raja. Akhirnya terjadi perlawanan rakyat yang dipimpin Burniat di kota Bengkasulu dan sekitarnya pada 
awal bulan April tahun 1873. Dalam perlawanan rakyat tersebut Asisten Residen Humme terbunuh. Kemudian, di susul Asisten Residen H.C Van Amstel dan Controlier Lais Castens pada 2 September 1873, tatkala sedang menyeberangi Sungai Bintunan yang mengalir ke laut di sebelah utara kota Lais menuju Muko-Muko. Terbunuhnya Asisten tersebut membuat Belanda mulai bertindak dan melakukan perlawanan, dengan meminta bantuan kekuatan ketentaraan yang dikirim Batavia dan Padang. Pada 9 September 1873 pertempuran terjadi diberbagai daerah Bengkulu, mulai Bintuhan, Seblat, Ketahun, Lais, Tanjung Terdana, Seluma dan sekitar kota Bengkulu.

Perlawanan tersebut akhirnya dapat diselesaikan pada 1978 atas kemenangan pihak Belanda. Rakyat hanya bisa mengikuti dan menaati peraturan yang diperintahkan oleh Belanda. Belanda mulai melanjutkan pemerintahan dengan membentuk satu daerah administratif keresidenan yang dikepalai residen.

Pada akhir tahun 1941, tepatnya pada 8 Desember 1941 terjadi perang Pasifik. Belanda menyatakan perang terhadap Jepang yang dipimpin Gubernur Jenderal Hindia Belanda, Jhr. Alidius W.L. Tjatda Van Starkenborch Strachouwer pada 18 Desember 1941. Perang tersebut membuat orang Belanda yang ada di setiap daerah ikut berperang. Terbukti dari penutupan sekolah yang memiliki guru kebangsaaan Belanda. Dengan kurangnya orang Belanda, membuat pemuda dan pelajar membentuk organisasi kecil, berupa organisasi olah raga, musik dan lain-lain. Organisasi tersebut berkembang menjadi besar. Pada 24 Februari 1942 tentara Jepang tiba di Bengkulu dengan penyerahan total dan tanpa syarat dari pemerintahan Belanda ke tentara Jepang pada 8 Maret 1942, dengan kejadian tersebut pemerintahan Belanda berakhir (Ranni, 1990).

\section{Masa Jepang}

Jepang mulai ke Bengkulu dipimpin Kolonel Kangki. Pasukan Jepang melakukan iring-iringan saat memasuki kota Bengkulu. Kedatangan Jepang bukan membawa nafas baru, tetapi menambah beban yang luar biasa. Penderitaan dan kesengsaraan akibat keserakahan Jepang sering dialami. Kebencian pada Jepang membuat pemuda bersemangat untuk melawannya. Dengan membentuk organisasi yang berawal dari membantu korban kebakaran dan mengumpulkan dana.

Meskipun kegiatan tersebut masih diawasi Jepang. Dengan rasa takut Jepang akan organisasi tersebut membuatnya mengubah menjadi Seinendan, organisasi yang dibentuk Jepang. Pemuda kala itu tidak bisa bertindak banyak, selain menyetujui yang diperintahkan Jepang. Jepang membentuk laskar yang diberi nama Heiho. Heiho adalah tentara yang diperbantukan langsung dan menjadi 
bagian tentara Jepang. Di susul dengan Gyugun, yang merupakan pendidikan atau pelatihan perwira pada 13 Desember 1943. Bermula dari yang diselenggarakan oleh Angkatan Darat di kota Pagaralam dan Angkatan Udara di Manna. Kesempatan pemuda untuk melawan Jepang dengan masuk Heiho dan Gyugun. Para perajurit diajarkan berbagai ilmu bersenjata dan cara menghadapi musuh. Perjuangan pemuda tidak sia-sia. Pada akhir Juli 1945, pemuda melakukan persiapan untuk mengadakan perlawanan terhadap Jepang.

Dengan berhati-hati supaya semua rencana tidak diketahui Jepang. Tinggal menunggu satu komando maka perlawanan tersebut terjadi. Berita kekalahan Jepang oleh Sekutu mulai menyebar. Akhirnya pasukan Gyugun resmi dibubarkan. Dalam pidato seorang pimpinan Gyugun di salah satu tempat, berkata bahwa peperangan ini tidak berakhir di sini, tetapi peperangan akan dimulai dari sekarang, dan disambung dengan mereka akan datang kembali sesudah sepuluh tahun (Pidato I Nomor Ue Taico di Ibul Manna pada bulan Agustus 1945) (Ranni, 1990).

\section{Berita Proklamasi dan Sambutan Masyarakat Bengkulu}

Berita kekalahan Jepang mulai terdengar oleh pejuang Bengkulu. Pada 14 Agustus 1945 Hamdan Mahyuddin dan rekannya berkunjung ke kediaman Letnan I Yamanaka. Dari kunjungan tersebut mereka mendapat kabar bahwa Indonesia telah merdeka dari siaran radio langsung dari Tokyo. Berita tersebut menyatakan bahwa perang dihentikan, untuk menghindari korban selanjutnya. Nawawi Manaf selaku pemimpin Gyugun di Lapangan Udara Padang Kemiling diberitahu bahwa Jepang kalah perang, dari seorang perwira Jepang. Di tambah pula dengan pernyataan seorang perwira Jepang kepada A. Rani Thalib bahwa Jepang sudah angkat senjata dalam berperang (Tim peneliti masa revolusi Bengkulu 19451950, 2002).

Berita kekalahan Jepang mulai tersebar di daerah Bengkulu. Akhir Agustus 1945 Manna merupakan kota pertama di Bengkulu yang menerima kemerdekaan oleh Buldani Masik, seorang bekas komandan Mesin Berat (M-23) di Markas Besar Gyugun di Pagar Alam. Selanjutnya di Kepah sekitar awal September. Berita kemerdekaan disebarkan dari mulut ke mulut oleh para mantan Gyugun dan Heiho.

Pada 25 September 1945, sekitar pukul 10.00 WIB, berita kemerdekaan Indonesia dikumandangkan di Curup. Nur Arifin membacakan teks Proklamasi disertai pengibaran bendera Merah-Putih dan menyanyikan lagu Indonesia Raya. Masyarakat mengikuti jalannya upacara dengan semangat dan khidmat. Berita kemerdekaan mulai tersebar di setiap daerah. Respon masyarakat Bengkulu sangat gembira. Mereka mengibarkan bendera merah putih di setiap rumah, 
walaupun tentara Jepang masih berkeliaran di Bengkulu. Pada 29 Agustus 1945 para pegawai PTT Bengkulu melaksanakan upacara bendera merah putih di depan kantor PTT. Namun esok harinya bendera diturunkan paksa oleh Jepang. Rakyat Bengkulu tidak takut kepada Jepang. Rakyat Bengkulu tetap mengibarkan bendera merah putih (Tim peneliti masa revolusi Bengkulu 1945-1950, 2002).

Pada 3 September 1945, secara resmi berita kemerdekaan dibawa oleh bekas pimpinan Gyugun, yaitu Rahim Damrah. Berita tersebut berupa surat kabar Palembang Shinbun yang berjumlah dua lembar yang berisi proklamasi kemerdekaan Indonesia 17 Agustus 1945 oleh Soekarno-Hatta (Tim Penyusun Sejarah dan Peranan SUBKOSS, 2003).

\section{Biografi Letnan I Nawawi Manaf}

Letnan I Nawawi Manaf lahir di Bengkulu 22 Maret 1923. Nawawi Manaf menempuh pendidikan umum dari HIS, MULO dan AMS. Sekolah terakhir yang ditempuh adalah kelas 1 A.M.S, sekolah yang didirikan Belanda. Ketika zaman Jepang, kemudian lanjut pendidikan militer Gyugun dan Heiho. Pendidikan basis Jepang berada di Pagar Alam. Pada tahun 1945 Nawawi Manaf diangkat menjadi Komandan TKR di Bengkulu. Pada saat itu sedang terjadi pembunuhan antek-antek NICA di Bengkulu pada 5 Oktober 1945. Nawawi Manaf saat itu menjadi komandan, di tangkap oleh Jepang pada 22 Oktober
1945. Pada 9 Desember 1945, Nawawi Manaf dibawa ke Padang Sekutu untuk ditahan bersama sembilan orang di penjara Muara Padang. Penahanan tersebut berkaitan dengan peristiwa pasar Bengkulu pada 5 Oktober 1945. Kemudian melarikan diri dari penjara Muara Padang pada 18 Oktober 1946 dan kembali ke Bengkulu. Selama dua tahun dari tahun 1947-1978 Nawawi Manaf menjabat menjadi Komandan Batalyon XXVI Garuda Mas Sriwijaya di Bengkulu.

\section{E. Makna Revolusi Fisik}

Revolusi fisik terjadi tahun 19451950. Berawal dari ketidakinginan bangsa asing untuk melepaskan Indonesia. Walaupun Indonesia telah merdeka, tetapi Belanda tetap ingin menguasai kembali. Kejadian ini dapat dikatakan sebagai bentuk revolusi kemerdekaan Indonesia.

Oleh karena sebagai puncak dari perjuangan rakyat untuk mempertahankan kemerdekaan, yang tersebar di berbagai daerah Indonesia. Salah satu daerah yang terlibat revolusi fisik adalah Bengkulu. Sebelum Bengkulu menjadi provinsi adalah keresidenan Bengkulu masa Belanda. Masa revolusi fisik di Bengkulu terjadi beberapa peristiwa pertempuran di kota Bengkulu, Kepahyang dan Curup.

\section{F. Makna Peranan}

Peranan adalah suatu yang menjadi bagian atau yang memegang pemimpin, terutama dalam terjadinya peristiwa. Peran bisa dimaknai sebagai peranan yang 
memiliki beberapa arti. Diantaranya aspek dinamis dari kedudukan, perangkat hakhak dan kewajiban, perilaku aktual dari pemegang kedudukan, dan bagian atau aktifitas seseorang (Imanuel C Florentinus, 2015). Peranan meliputi tiga hal dalam penokohan seseorang, antar lain:

1. Peranan yang meliputi norma yang berhubungan dengan kedudukan seseorang dalam organisasi. Peranan merupakan tatanan peraturan yang dapat membimbing anggotanya. Norma tersebut terdiri, Pertama, cara yaitu seseorang yang memiliki peranan lebih menonjol dalam hubungan antar individu atau kelompok dalam organisasi. Kedua, kebiasaan seseorang yang memiliki peranan yang besar dalam organsasi, biasanya seseorang melakukan kegiatan berulang-ulang dalam bentuk yang sama, membuktikan unsur menyukai kegiatan tersebut. Ketiga, tata kekuatan, yakni seseorang adalah cerminan sifat yang menjadi patokan untuk anggotanya, serta Keempat ialah adat istiadat, seseorang memiliki perilaku yang menjunjung tinggi adat istiadat dan selalu mempedomani untuk anggotanya.

2. Peranan adalah konsep yang dapat dilakukan dalam organisasi. Peranan merupakan perilaku yang penting bagi tatanan sosial masyarakat dalam organisasi (Stamadova, 2017).

\section{Metode Penelitian}

Metodologi penelitian berasal dari kata metode yang artinya cara yang tepat untuk melakukan sesuatu, dan Logos artinya ilmu pengetahuan. Artinya, metodologi adalah cara melakukan sesuatu dengan menggunakan pikiran untuk mencapai tujuan. Selanjutnya penelitian adalah bentuk kegiatan mencari, mencatat, merumuskan dan menganalisis sampai menyusun laporan. Metodologi penelitian merupakan cara untuk mengetahui sesuatu pada penemuan, pengembangan atau menguji kebenaran, logis dan empiris dengan menggunakan metode ilmiah. Metodologi sejarah tersebut dengan cara observasi dalam menyeleksi fakta dari sumber, dapat mempertanggungjawabkan data penelitian, serta dibuktikan kebenarannya (Irwanto, 2014).

Dengan demikian, metodologi penelitian sejarah sebagai proses yang tersusun sistematis dalam mencari data, dengan tujuan untuk menjawab pertanyaan kejadian masa lalu, supaya mendapatkan pemahaman yang baik dari penelitian. Dalam penulisan ini, menggunakan metode historis. Metode historis merupakan metode penelitain yang meneliti sesuatu yang terjadi masa lampau, dengan tujuan menemukan generalisasi peristiwa masa lampau (Suryana, 2012). Langkah-langkah penelitian ini tersusun sebagai berikut: 


\section{A. Heuristik}

Heuristik berasal dari bahasa Yunani Heuriskein yang artinya menemukan. Heuristik diartikan sebagai tahap awal untuk mencari, menemukan, dan mengumpulkan sumber data. Supaya dapat mengetahui bentuk kejadian masa lalu. Dalam heuristik, untuk mencari sumber penelitian sejarah, terbagi menjadi sumber tertulis, sumber lisan, dan artifact.

\section{B. Kritik Sumber}

Kritik adalah menilai dengan otentik kebenaran atau tidak sesuatu sumber dan seberapa jauh kualitas sumber itu. Fungsi kritik sumber untuk mencari ketepatan dan kebenaran sumber yang dibutuhkan. Dengan tujuan, penelitian dapat dipertanggungjawabkan dan sejalan dengan tema yang diangkat dalam menjawab masalah penelitian. Kritik sumber terbagi menjadi dua, yaitu kritik ekstern untuk menentukan sumber yang diperoleh tepat atau tidak sebagai referensi penelitian. Kritik intern menentukan sumber dari kritik ekstern apakah bisa digunakan sebagai fakta sejarah.

\section{Penafsiran/Interpretasi}

Interpetasi adalah menetapkan makna dan saling berhubungan antara beberapa fakta yang diperoleh. Fakta tersebut merupakan sumber yang diperoleh peneliti dalam menjawab permasalahan yang diteliti. Melalui fakta peneliti dapat mereview jawaban tepat atau tidak. Kemudian dihubungkan dengan teori, sehingga penelitian dapat membuat pandangan baru bersifat ilmiah. Dalam penelitian ini, penulis mengambil peran tokoh pejuang Bengkulu masa revolusi fisik dpada 1945-1949. Dari berbagai sumber yang diperoleh, akan menjawab rumusan masalah dengan tepat, dengan sumbersumber yang valid (Alian, 2005).

\section{Historiografi/Penulisan}

Histroriografi merupakan ilmu yang mempelajari praktik penulisan hasil penelitian dan disusun berdasarkan serialisasi. Ciri-ciri historiograi yang baik harus membahas kronologi secara tertata, dan disusun berdasarkan sebab dan akibat serta imajinasi (Irwanto, 2014).

\section{E. Pendekatan}

Pendekatan adalah titik awal dalam memandang permasalahan. Dengan tujuan untuk meninjau permasalahan. Dalam penelitian ini, penulis menggunakan pendekatan ilmu sosial, berupa ilmu politik dan sosial. Pendekatan politik untuk melihat peran Nawawi Manaf dalam memimpin perjuangan rakyat Bengkulu masa revolusi fisik, banyak prestasi.

Seperti menjadi pempinan TKR, menjabat menjadi Komandan Batalion 26 Garuda Mas Sriwijaya di Bengkulu, pada agresi Militer Belanda II Nawawi Manaf memimpin dalam gerilya melawan Belanda di Bengkulu dan, banyak pengorbanan yang bertujuan mempertahankan kemerdekaan. Dalam revolusi fisik di Bengkulu, Nawawi Manaf berpangkat Letnen I (Tim Peneliti 
Nawawi Manaf dalam Perjuangan Kemerdekaan di Bengkulu, 2003). Pendekatan sosial juga digunakan untuk melihat peran Letnan I Nawawi Manaf di bidang sosial. Letnan I Nawawi Manaf bisa berhubungan atau komunikasi dengan tentara Jepang. Namun di tahan dan di penjara oleh tentara Jepang.

Letnan I Nawawi Manaf dengan rombongan pejuang Bengkulu memiliki hubungan yang baik. Sehingga dapat mengusir penjajah. Meskipun kadang terdapat selisih yang berujung pada pengasingan terhadap dirinya sendiri. Tetapi dengan semangat juang anti penjajah yang membuat dapat mempertahankan kemerdekaan di Bengkulu (Tim Peneliti Masa Revolusi Fisik Bengkulu 1945-1950, 2002).

\section{Hasil Dan Pembahasan}

\section{A. Peran Letnan I Nawawi Manaf Awal}

\section{kemerdekaan Indonesia di Bengkulu}

Gema proklamasi kemerdekaan di sambut suka cita rakyat Bengkulu. Berita kemerdekaan Indonesia berawal dari Ali Hanafiah kepada Nawawi Manaf, yang berisi kemerdekaan telah diproklamasikan oleh Soekarno-Hatta pada 17 Agustus 1945. Nawawi Manaf yang mendengar berita tersebut langsung menghubungi Gubernur Jepang yang bernama Suchokan Inumata dan wakilnya. Tujuannya untuk menyampaikan perkembangan situasi dari berita kemerdekaan Indonesia. Nawawi
Manaf sebagai pejuang kemerdekaan Indonesia, tetapi juga memiliki hubugan baik dengan tentara Jepang, dapat dilihat tatkala meminta bantuan makanan dan senjata kepada tentara Jepang untuk pasukan yang berjaga dalam keamanan kemerdekaan Indonesia (Tim Peneliti Nawawi Manaf dalam Perjuangan Kemerdekaan di Bengkulu, 2003).

Proklamasi kemerdekaan yang ditandai dengan kekalahan Jepang, di Bengkulu membentuk organisasi kemiliteran sebagai pelengkap pemerintah Indonesia di daerah, serta membentuk aparat pertahanan keamanan. Pada 10 September 1045, di Bengkulu dibentuk Angkatan Pemuda Indoneia (API) yang dipelopori Nawawi Manaf. Tugas utama API adalah menyebarluaskan informasi di semua daerah Bengkulu mengenai kemerdekaan Indonesia.

Pada tanggal yang sama pula pemuda Bengkulu mengadakan pertemuan yang diadakan di rumah kediaman Nawawi Manaf di Jalan Pintu Bantu. Hasil pertemuan membahas pembentukan organisasi yang diberi nama Barisan Pemuda Indonesia. Di ketuai Nawawi Manaf, wakil ketua M.Z. Ranni, sekretaris Hadis Lani dan wakil sekretaris Inuh Mustafa. Mereka semua adalah bekas anggota gyugun (Ranni, 1990). Pada 20 September 1945, didirikan BKR (Badan Keamanan Rakyat) di Bengkulu yang dipimpin Nawawi Manaf. Dibentuknya BKR 
karena adanya keputusan dari pemerintah pusat dari PPKI pada 22 Agustus 1945. Keputusan tersebut disampaikan oleh koordinator daerah Dr. A. K. Gani dari Palembang. Tujuan didirikan BKR untuk mempertahankan keamanan rakyat dengan menyatukan semua organisasi pemuda yang ada.

Tanggal 25 September 1945, BKR ditingkatkan menjadi Penjaga Keamanan Rakyat (PKR) yang dipimpin Nawawi Manaf. PKR dibentuk di setiap Keresidenan Bengkulu, yaitu Manna, Kepahyang, Curup, Muara Aman, dan Lais. Nawawi Manaf menyusun pengurus PKR, yakni:

1. Manna dengan daerah tanggung jawab Kewedangan Manna dengan pasukan berbentuk kompi, diketuai Buldami Masik dan wakil Meranuddin Taya, serta pengurus dipimpin Rahim Damrah.

2. Bintuhan dengan daerah tanggung jawab Kewadangan Kaur dengan pasukan berbentuk kompi yang dipimpin Syamsul Badrun.

3. Kepahyang dengan daerah tanggung jawab Kecamatan Kepahyang dengan pasukan berbentuk kompi dipimpin Zamhari Abidi

4. Curup dengan daerah tanggung jawab Kecamatan Curup dan Padang Ulak Tanding dengan pasukan berbentuk kompi yang dipimpin Z. Arifin Jamil.

5. Muara Aman dengan daerah tanggung jawab Kewadangan Lebong dengan pasukan berbentuk kompi dipimpin A. Rani Talib.

6. Daerah lain seperti Kota Bengkulu, Kawadangan Bengkulu dan Seluma, Kewadangan Lais, dan Kewedangan Muko-Muko dibawah komando M. Safei Ibrahim (Ranni, 1990).

Nawawi Manaf memasukkan pemuda Bengkulu yang memiliki tenaga potensial dan berumur muda ke anggota PKR. Dari beberapa sumber mengatakan bahwa anggota PKR umumnya masih muda. Bahkan ada yang masih duduk di sekolah rendah. Meski mereka masih muda tetapi dapat diandalkan. Bukan tanpa alasan Nawawi Manaf merekrut yang masih muda. Salah satunya keadaan yang mendesak, dari kurangnya para pejuang yang bertugas membela kemerdekaan. Mereka diberi bekal untuk mengembangkan potensi yang ada, dengan tujuan agar dapat membela tanah air (Tim Peneliti Nawawi Manaf dalam Perjuangan Kemerdekaan di Bengkulu, 2003).

Nawawi Manaf yang mengemban amanah sebagai pemimpin PKR tidak berjalan dengan mulus. Ada hambatan yang harus dihadapi. Masyarakat Bengkulu saaat itu masih belum percaya sepenuhnya kabar kemerdekaan. Bahkan menganggap pemerintah pusat bermain politik. Ditambah dengan masyarakat Bengkulu bekas pegawai Jepang yang masih setia dengan majikannya. Nawawi Manaf beserta anggota berusaha untuk meyakinkan 
masyarakat Bengkulu bahwa, kemerdekaan benar adanya dan harus mengusir penjajah yang masih berada di Bengkulu. Orangorang Jepang waktu itu sudah tidak memiliki kekuatan dan kekuasaan menghadapi tentara sekutu. Namun mereka belum mau untuk melepaskan Bengkulu. Para petinggi Jepang berusaha melakukan aksi yang tujuannya, untuk bekerjasama dengan Nawawi Manaf dalam organisasi PKR.

Tanpa pikir panjang, Nawawi Manaf menolak apapun yang ditawarkan oleh oknum Jepang tersebut. Nawawi Manaf dan anggotanya melakukan berbagai cara untuk meyakinkan bahwa Indonesia telah merdeka. Salah satunya dengan cara mereka menyebarkan pamflet tentang kemerdekaan Indonesia. Untuk pertama kali bendera Merah putih dikibarkan di daerah Manna di Padang Siaang pada 29 September 1945.

Pengibaran bendera dipimpin Merahnuddin Taya. Lebih lanjut, pengibaran bendera di Kepahyang dipimpin Muryadi Priatmo (Ranni, 1990). Mr. T. M Hassan telah diangkat Pemerintah Indonesia sebagai Gubernur Sumatera, dan Ir. Indra Caya diamanahkan sebagai Residen Bengkulu. Mendengar berita tersebut, masyarakat dan petinggi Bengkulu menyambut suka cita dan mengibarkan bendera Merah Putih. Gubenur Sumatera Mr. I. M Hassan memerintahkan seluruh provinsi di
Sumatera untuk segera mengibarkan bendera. Nawawi Manaf memerintahkan kepada anggotanya untuk menyampaikan pesan dari Gubernur Mr. I. M Hassan guna mengibarkan Bendera. Nawawi Manaf juga memerintahkan untuk selalu mengawasi kegiatan masyarakat Bengkulu. Pengibaran bendera Merah Putih di Bengkulu mengalami berbagai penolakan.

Penolakan tersebut terjadi diberbagai perumahan dan kantor. Mereka yang enggan mengibarkan bendera adalah yang masih pro dengan Jepang. Nawawi Manaf dan rekan-rekannya berusaha melakukan pendekatan diplomasi ke pihak Jepang. Diplomasi ini meminta supaya bendera Jepang dapat diturunkan. Kesepakatan ini berlangsung di kediaman pimpinan Jepang di Bengkulu, yaitu Z Inomata. Dengan berbagai cara, akhirnya Jepang menyetujui permintaan Nawawi Manaf untuk menurunkan bendera Jepang. Bendera Jepang yang terpasang di halaman gedung keresidenan dan diganti dengan bendera Merah Putih.

Setelah diplomasi selesai, Jepang tidak diam, namun juga ikut berpendapat. Mereka mengatakan jika kekuasaan Jepang masih kuat. Nawawi Manaf yang mendengar pernyataan tersebut, langsung mengambil sikap kontra terhadap tentara Jepang. Pada 10 Oktober 194, terjadi pertempuran tentara Jepang dengan PKR di Manna. Kejadian bermula akibat perundingan yang gagal antara PKR Manna 
dengan tentara Jepang. Pertempuran dipimpin oleh pimpinan PKR Manna yaitu Rahim Dammrah, Buldani Masik, Merahnuddin Taya, Haji A. Said, Ismail Rahman, dan Ustadz Berziah. Akibat pertempuran ini, terdapat anggota PKR yang gugur seperti Bakhsir. Yang mengalami luka-luka, diantaranya Maskasa, Zakaria Mahyat, Merahnuddin Taya dan Buldani Masik.

Pertempuran ini juga mengakibatkan beberapa tentara Jepang tewas dan persenjataan milik Jepang dirampas. Nawawi Manaf dan rekanrekannya melakukan musyawarah. Guna membahas persoalan pertempuran di Manna dan perundingan yang tidak mencapai kata sepakat. Hasil keputusan musyawarah adalah:

1. Anggota PKR yang diketahui pihak Jepang, yang ikut dalam pertempuran pada 10 Oktober 1945, mereka bergerak di bawah tanah atau dapat dikatakan tetap bergerak tetapi tidak secara resmi.

2. Susunan pengurus PKR di Manna dibentuk baru.

Pada 18 Oktober 1945, mulai diresmikan pengurus PKR di Manna yang baru, yang diketuai Bahmada Rustam dengan anggota jamaludin, Z.A. Syahril, Rahim Harun, Alimudin, Aidin, Junusi, Jusirana, Suardi Naum. Untuk memantau kondisi di Manna, maka Nawawi Manaf mengutus A. Rusdi, kepala Contactbureau pada kantor Residen Bengkulu.
Selanjutnya, menyusul dari PKR Bengkulu berjumlah 20 orang yang dipimpin Zahari Tani, Inuh Mustafa, Raden Hadi, Salim Bayan, Sutan Yakup, Zairun, Indra Mahadi, Sulaiman Kayum, Mik (Botak). Perundingan kedua antara PKR dengan tentara Jepang diadakan kembali. Dari pihak PKR dipimpin Ismail Rakhman dan Zen (dari rombongan PKR Bengkulu), Suwardi Naum, dan Hasan selaku juru bicara. Dari pihak tentara Jepang dipimpin Kapten I No Ue dan Kapten Mera Kame.

Perundingan tersebut tetap saja tidak membuahkan hasil atau mengalami kegagalan (Ranni, 1990). Mendengar kondisi Keresidan Bengkulu yang kacau, perundingan tidak berhasil dan perlawanan terhadap Jepang, akhirnya membuat anak buah Nawawi Manaf melakukan tindakan sendiri. Tindakan yang dilakukan tanpa mendapat persetujuan dari pimpinan pusat PKR.

Mereka melakukan penyerangan terhadap tentara Jepang. Akibat tindakan tersebut tentara Jepang melakukan penangkapan terhadap anggota PKR di Manna. Termasuk beberapa anggota dari rombongan yang datang dari Bengkulu, antara lain Ahmad Mahyudi Alimuddin, Yasin, Zais, Amat Bugis, Yusirana, Aliteman, Zen, Siurna, Basri Said, Nusirwan, Herman, Abusahab dan Basulana (Tim Peneliti Nawawi Manaf, dalam Perjuangan Kemerdekaan di Bengkulu, 2003). Awal minggu ke empat bulan Oktober 1945, 
Pemerintah Daerah Bengkulu secara resmi masih dipegang Jepang. Meskipun telah ada Gubernur Sumatera dan Residen Bengkulu. Jepang belum bersedia untuk menyerahkan pemerintah daerah Bengkulu kepada Indonesia untuk daerah Bengkulu. Nawawi Manaf dan rombongan melakukan berbagai cara untuk melawan petinggi Jepang. Dari hasil musyawarah mufakat petinggi Bengkulu, Nawawi Manaf memutuskan mengadakan pemogokan serentak seluruh daerah Bengkulu.

Nawawi Manaf memerintahkan kepada anak buahnya untuk menyebarluaskan perintah pemogokan kerja di setiap daerah. Nawawi Manaf dan anggota PKR selalu mengawasi agar rencana tersebut dapat berjalan sebagaimana mestinya. Pada 25 Oktober 1945, Nawawi Manaf memberikan perintah bahwa tanggal 26 Oktober 1945 di mulai pelaksanaan pemogokan kerja.

Perlaksanaannya mulai pukul 00.05 dini hari sampai selesai, dengan perintah pemogokan umum. Blokade total terhadap Jepang harus dilakukan seluruh masyarakat Bengkulu. Tidak masuk kerja dan tidak melakukan interaksi dengan orang Jepang adalah bentuk pemogokannya. Semua pusat pembelanjaan (toko dan pasar) tidak melayani pembeli dari orang Jepang. Perlawanan masyarakat Bengkulu membuat Jepang mengirim utusan untuk berdamai dan berjanji memberikan kekuasaan kepada rakyat
Bengkulu. Pada 27 Oktober 1945, dilakukan upacara penyerahan resmi dari Jepang kepada Indonesia untuk daerah Bengkulu. Penyerahan dilakukan oleh bekas Residen Jepang Z. Inomata. Dari pihak Indonesia di wakili Residen Bengkulu Ir. Indra Caya. Nawawi Manaf, selaku pimpinan PKR Bengkulu, juga menandatangani naskah penyerah atau timbang terima. Selesainya upacara, pemogokan juga berakhir dan semua aktifitas dipulihkan lagi (Ranni, 1990).

Nawawi Manaf mendapatkan berita bila tentara Sekutu datang ke Bengkulu dari Palembang. Kemudian pada 1 November 1945 di Curup melintas mobil sedan kecil berwarna hitam. Mobil itu ditumpangi salah satu orang Belanda yang bernama Smit, bekas pegawai listrik di Tes pada zaman Belanda. Di Belalau, sedan tersebut diperiksa, dan menemukan senjata selaras senapan.

Setelah pemeriksaan, sedan itu di giring PKR Padang Ulak Tanding untuk melanjutkan perjalanan menuju Lubuk Linggau. Sampai di Lubuk Linggau, PKR menggiringnya menuju ke Palembang. Beberapa peristiwa di daerah bengkulu masa tersebut, diantaranya:

1. Peristiwa Pasar Bengkulu

Pada 5 November 1945, terjadi peristiwa Pasar Bengkulu yaitu pembunuhan ketiga orang Inggris. Peristiwa tersebut berawal dari kedatangan tiga orang Inggris pada 3 
November 1945. Sekitar pukul 19.00 terlihat sedan warna biru datang dari arah Lubuk Linggau. Di Curup, sedan tersebut ditahan untuk di interogasi. Setelah mengetahui tujuan mereka, PKR Curup menghubungi markas PKR pusat di Bengkulu. Mendengar berita tersebut, Nawawi Manaf mengutus Margono untuk mencari informasi mengenai kondisi yang terjadi. Dari informasi yang diterima, mereka akan pergi ke tambang emas Lebong Tandai.

Pada 5 November 1945, Nawawi Manaf dan rekannya mendatangi pimpinan umum pasukan PKR di markas PKR Tengah Padang. Pertemuan tersebut membahas kedatangan orang Inggris tersebut. Nawawi Manaf memerintahkan supaya seluruh pasukan PKR dapat mengawasi dan menghalangi tujuan mereka, yang ingin pergi ke tambang emas Lebong Tandai. Kecurigaan dengan orang Inggris semakin menguat.

Hal ini sebab di Lebong Tandai tidak terdapat tentara Jepang, tawanan perang, orang-orang yang bersangkutan dengan mereka dan tidak ada sangkut pautnya dengan tugas tentara sekutu. Nawawi Manaf memerintahkan kepada anak buahnya untuk memasang penghalang. Penjagaan ketat di setiap pos jaga juga dilakukan. Nawawi Manaf juga menginstruksikan M. Jalil untuk menambah penghalang di awal
Jembatan, menambah jumlah anggota PKR di depan jembatan, memasang penjagaan di seberang jembatan serta anggota lain berpencar dan mengambil perlindungan. Para anggota PKR dibagi menjadi beberapa tugas untuk menjaga di depan dan seberang jembatan. Sedan tersebut yang membawa orang Inggris dapat lolos dari penghalang di pos penjaga, sebelum akhirnya berhenti di depan jembatan.

M. Syafei yang ditugaskan menjaga di depan jembatan, dengan sigap menghalangi mobil sedan untuk melaju. Tepat di belakang M. Syafei berdiri M. Daud anggota PKR yang masih muda. Saat itu, M. Daud melihat salah seorang dari orang Inggris menyodorkan pistol kepada M. Syafei. M. Syafei berkata kepada M. Daud "mana tombak", tetapi para anggota PKR yang telah bersiapsiap justru salah memahami. Mereka mengira perintah itu adalah aba-aba untuk menyerang.

Akhirnya anggota PKR langsung menyerbu mobil sedan tersebut, sehingga membuat dua orang meninggal di tempat. Satu lagi berhasil lolos dan melarikan diri ke pelabuhan lama tempat pos Jepang. Mereka adalah Kapten Ir. Trevoro bekas karyawan tambang emas Lebong Tandai pada zaman Belanda, Kapten Smith, dan Kapten Dr. Mycree. Tentara Jepang yang mendengar peristiwa itu langsung 
menghubungi Residen Bengkulu untuk meminta nama yang telah membunuh orang Inggris tersebut. Bahkan meminta juga hasil rampasan senjata supaya segera diserahkan. Jepang meminta kedua jasad mayat Inggris itu yang telah dikubur, digali kembali dan diserahkan kepada mereka. Saat bersamaan datang pesawat udara dari Palembang. Jepang menyerahkan ketiga korban peristiwa Pasar Bengkulu kepada Sekutu.

Pesawat tersebut melanjutkan perjalanan menuju Palembang. Jepang yang berpihak dengan Sekutu turut andil dalam penyelidikan peristiwa Pasar Bengkulu. Tentara Jepang mulai melakukan penggeledahan dan pemeriksaan di setiap rumah penduduk untuk mencari senjata rampasan. Tidak ada hasil yang di dapat. Tentara Jepang mengeluarkan ultimatum ke pimpiman Bengkulu, "jika sampai tanggal 8 November 1945 pembunuh dan senjata serta alat rampasan belum diketemukan, kami akan mengadakan tindakan keras".

Pada 10 November 1945, dua buah kapal perang Inggris mendarat di depan pelabuhan Bengkulu. Mereka memberi ultimatum ke pimpinan Bengkulu, "jika dalam 24 jam pembunuh dan orang yang bertanggung jawab tidak diserahkan, Bengkulu akan dihancurkan".
2. Dipenjara Di Muara Aman

Nawawi Manaf selaku wakil komandan TKT tidak takut ancaman tentara Jepang maupun Inggris. Bahkan Nawawi Manaf beserta anak buahnya menyusun strategi untuk melakukan pertempuran selanjutnya. Tentara Jepang akhirnya menangkap Nawawi Manaf dan anak buahnya yang berada di hutan. Pertempuran yang direncanakan akhirnya gagal. Nawawi Manaf dan kesembilan pasukan di giring menuju penjara di Muara Padang.

Yaitu, Syapie Ibrahim, Syofyan Kasim, Z. Asyikin, Annas Marzuki, M. Yunus Muhammad, Nawawi Zakirun, Amin Aker, Ilyas Bakti dan M. Daud Awam. Pada 27 November 1945, Mayor Barlian diangkat menjadi Komandan TKR yang baru (Tim Peneliti Sejarah Revolusi Kemerdekaan, 1979). Pada 14 Agustus 1946, Nawawi Manaf dengan tahanan lain, dapat meloloskan diri dari penjara Padang. Nawawi Manaf dan rekan-rekannya bergabung kembali dengan pasukan Brigade Garuda Emas.

\section{B. Peran Letnan I Nawawi Manaf Masa Agresi Militer Belanda I di Bengkulu}

Pada 21 Juli 1947 sampai 17 Januari 1948, terjadi Agresi Militer Belanda I di Bengkulu. Agresi Militer Belanda I, tidak terlalu berpengaruh di daerah Bengkulu. Pada saat itu pasukan Belanda fokus dengan wilayah Palembang. Nawawi Manaf yang menjabat sebagai perwira TT II 
Sumatera Selatan. Pada 1 Juli 1948 Devisi Garuda VII yang berada di Lubuk Linggau menjadi Sub Teritorium Sumatera Selatan membawahi:

1. Sub Teritorium Palembang dengan kedudukan di Muara Beliti.

2. Sub Teritorium Lampung dengan kedudukan di Tanjung Karang.

3. Sub Teritorium Jambi dengan kedudukan di Jambi dan

4. Sub Teritorium Bengkulu denga kedudukan di Bengkulu.

Sementara Sub Teritorium di Bengkulu, Nawawi Manaf ditunjuk sebagai komandan Batalyon XXVI yang menggantikan Mayor Burhan Dahri (Ranni, 1990). Nawawi Manaf sebagai pemimpin Batalyon XXVI, membentuk lima Kompi untuk menghadapi Belanda yang datang dari laut. Kelima Kompi tersebut, yaitu:

1. Kompi Mortir yang berada di Kepahyang yang dipimpin oleh Letnan Dua Zainal Abidin Gafur.

2. Kompi Letnan Satu Djarab berada di Bengkulu ditugaskan dalam pertahanan arah Selatan.

3. Kompi Letnan Dua Sani Jakfar berada di Bengkulu ditugaskan dalam pertahanan arah Utara.

4. Kompi Letnan Dua M. Yunus berada di Bengkulu ditugaskan dalam pertahanan arah Penanjung.

5. Kompi Letnan Dua A. Mahyudi yang berada di Bengkulu dibantu ALRI pimpinan Letnan Dua Win Tamawiwi (SUBKOSS, 2003).

Tujuan pembagian ini adalah untuk meningkatkan pertahanan dan memudahkan pemantauan kondisi daerah dalam Agresi Militer Belanda II.

\section{Peran Letnan I Nawawi Manaf Masa Agresi Militer Belanda II di Bengkulu} Agresi Militer Belanda II di Bengkulu terjadi pada 31 Desember 1945. Berawal dari sebuah pesawat terbang Belanda yang menembak daerah jembatan Kencing sekitar pukul 11.00 WIB. Pukul 16.00 WIB, di dekat Pulau Tikus ada sebuah kapal perang Belanda. Sekitar tengah malam, kapal Belanda mulai melakukan penembakan dengan meriam dan senjata berat yang diarahkan ke kota Bengkulu. Nawawi Manaf dengan sebagian anggota dan pimpinan yang lain mendiskusikan untuk melawan tentara Belanda.

Agresi Militer Belanda II terjadi di tiga wilayah di Karesidenan Bengkulu, yaitu Front Pertempuran di Bengkulu, Front Pertempuran di Curup, dan Front Pertempuran di Kepahyang. Karesidenan Bengkulu di bagi beberapa Batalyon yang tersebar di berbagai daerah. Batalyon tersebut langsung di bawah komandan Sub Teritorium Bengkulu Letnan Kolonel Barlian (SUBKOSS, 2003). Nawawi Manaf sebagai pemimpin pasukan Batalyon XXVI yang memimpin pertempuran di Bengkulu. Pada 5 Januari 1949, kota Bengkulu di serang tentara Belanda dari laut dengan 
kapal perang dan pesawat udara. Dengan pasukan Batalyon XXVI, Nawawi Manaf melakukan perlawanan yang hebat terhadap Belanda. Dalam pertempuran tersebut, Nawawi Manaf dibantu pasukan ALRI yang dipimpin Letnan Dua Wim Tamawiwi. Pasukan Belanda mulai memasuki daerah Bengkulu dan menguasai berbagai tempat di Bengkulu.

Salah satunya benteng Maiborought dan berlanjut di arah Sumer Melele dan Tengah Padang. Pasukan Batalyon XXVI manarik diri ke luar kota Bengkulu menuju arah Selatan, Utara dan Timur, dan sekeliling kota Bengkulu. Dengan begitu pasukan Belanda menduduki seluruh kota Bengkulu. Nawawi Manaf sebagai Komandan Batalyon XXVI yang dibantu Kapten Ir. Safuan Gatam, melakukan pembumihangusan di berbagai tempat sebagai bentuk perlawanan Belanda.

Pembumihangusan terjadi di wilayah jembatan pasar Bengkulu, jembatan taba Terunjam, jembatan Tanjung air, Gedung Karesidenan Bengkulu dan Benteng Malborought (SUBKOSS, 2003). Nawawi Manaf membagi pasukannya menjadi tiga front, yakni:

1. Front Utara, dipimpin Letnan I Syafei Ibrahim dengan kawasan pertahanan Bengkulu sebelah utara. Mulai sebrang Sungai Serut ke daerah Muko-Muko.

2. Front Tengah yang dipimpin Letnan II A. Mahyudin Awab dan Latnan II Wim Tamawiwi.
3. Front Selatan yang dipimpin Letnan I Jarab terdiri dari kawasan pertahanan, mulai Sukarami sampai daerah Manna.

Setiap front terbagi lagi dari berbagai sektor yang dibawahi front tersebut. Nawawi Manaf mengutus tiga anggotanya, yaitu Sersan A. Rahman Idup, Mokhtar Azhari dan A. Rivai Mursalin. Mereka ditugaskan untuk mencari informasi tentang pasukan Belanda di Kapahyang. Harapannya informasi yang diperoleh tersebut berguna tatkala menghadapi perlawanan Belanda.

Namun pada kondisi yang tidak berpihak bagi mereka, Nawawi Manaf mengutus beberapa anggota secara berulang-ulang untuk memasuki kota Bengkulu dengan tugas dan keperluan tertentu. Mereka adalah Firdaus Burhan, Pimpinan Propaganda dan Achmadi Dalip (Ranni, 1990). Perlawanan terjadi di berbagai daerah. Seluruh pimpinan pasukan dengan segenap jiwa dan raga melawan Belanda.

Oleh karena, pasukan Belanda tidak berhenti menyerang Bengkulu. Penyerangannya bukan hanya di darat, melainkan terjadi juga di udara. Pertempuran itu menyebabkan gugurnya pasukan Bengkulu, termasuk salah satunya adalah orang tua dari Nawawi Manaf. Peristiwa tersebut terjadi di Pondok Kubang pada 25 Januari 1945. Tentara Bengkulu sempat kewalahan ketika menghadapi Belanda. Perbedaan yang jauh 
antara pasukan Belanda yang memiliki kendaraan perang dan senjata canggih, berbeda dengan pasukan Bengkulu yang hanya senjata sederhana. Meskipun berbeda tidak membuat pasukan Bengkulu menyerah. Masyarakat Bengkulu turut membantu dalam perlawanan Belanda. Nawawi Manaf sebagai pimpinan Batalyon XXVI mengikutsertakan masyarakat untuk melakukan berbagai serangan.

Nawawi Manaf memerintahkan anggotanya, yang terbagi pada, Pertama, mereka melakukan penyerangan terhadap pos Belanda di Dusun Surabaya. Kedua, penyerangan terhadap pos Belanda Jembatan Gedang yang dipimpin Vabdrug Samsudin Youw dan Ketiga, penyerangan terhadap pos Belanda di Pekan Sabtu dan Padang Kemiling dipimpin Letnan Satu Djarab dan Amana. Kemudian diikuti aksi pencegatan terhadap Belanda dari arah Bengkulu ke Pekan Sabtu di Dusun Sukarami, yang dipimpin Vabdrug Samsudin Youw dan Supardi.

Tanggal 20 April 1949, Nawawi Manaf dan pimpinan lain menghadiri pertemuan yang dipimpin komandan STB Letnan Kolonel Barlian. Pertemuan tersebut membicarakan rencana melawan Belanda dan tetap memperkokoh pertahanan daerah Selatan. Di bantu pula dengan mempersiapkan tenaga tempur, bahan makanan, senjata dan lain sebagainya. Pada Juni 1949, terjadi beberapa pertempuran antara TNI-Subkoss melawan Belanda. Dalam pertempuran itu sejumlah anggota TNI gugur. Pertempuran tersebut terjadi di Curup dan Kepahyang (SUBKOSS, 2003). Pada 26 November 1949, Letnan Kolonel Barlian membentuk satu delegasi supaya bisa masuk ke kota Bengkulu. Tujuannya untuk serah terima seluruh daerah Bengkulu dari Belanda. Nawawi Manaf sebagai pimpinan Batalyon XXVI dan pimpinan Batalyon lainnya ditugaskan: 1). menjaga keamanan dan ketertiban serta tidak ikut campur tangan wewenang sipil dan politik, 2). jumlah penduduk dalam daftar itu, hanya merupakan pendudukan permulaan,

3). kelebihan personil setiap Batalyon sesudah selesai pengovenan seluruh STB, berangsur menduduki daerahnya masing-masing, sesuai perintah penerapan tanggal 26 November No.2070/6/b/SM, dan 4). pergerakan atau perubahan harus segera dilaporkan ke atasan melalui kurir atau telepon. Perintah tersebut harus dilaksanakan mulai 2 Desember 1949. Hingga pada akhirnya tanggal 4 Desember 1949, pemindahan kekuasaan dari Belanda ke Indonesia mulai dilaksanakan.

\section{Penutup}

\section{Kesimpulan}

Peranan Letnan I Nawawi Manaf di Bengkulu dalam revolusi fisik terbagi menjadi tiga periode. Pertama, tahun 1945 sampai 1946 Nawawi Manaf melakukan 
berbagai cara supaya masyarakat Bengkulu dapat menerima Indonesia telah merdeka. Selain itu juga berusaha supaya Jepang di Bengkulu tidak mencampuri urusan ke pemerintah Bengkulu. Nawawi Manaf memimpin berbagai organisasi kemiliteran, seperti API, BKR, PKR dan menjadi wakil Komandan TKR. Pada akhir tahun 1945, Nawawi Manaf di penjara oleh Inggris di Muara Padang. Sebagai akibat terlibat peristiwa di Pasar Bengkulu yang menewaskan dua orang Inggris. Tepatnya tanggal 14 Agustus 1945, Nawawi Manaf dan beberapa rekannya berhasil meloloskan diri dari penjara di Muara Padang. Kemudian mereka bergabung kembali ke pasukan Brigade Garuda Emas. Kedua, pada tahun 1947 Nawawi Manaf menjabat sebagai Perwira TNI TT II Sumatera Selatan.

Pada 1 Juni 1948, Nawawi Manaf ditunjuk Divisi Garuda VIII sebagai Komandan Batalyon XXVII di Bengkulu, menggantikan Mayor Burhan Dahri. Pada tahun ini Bengkulu juga mengalami Agresi Militer Belanda II. Nawawi Manaf beserta rekan-rekannya berupaya untuk melindungi Bengkulu dari Belanda yang ingin menjajah kembali, sehingga petempuran tidak dapat dihindari. Ketiga, tahun 1949 Agresi Militer Belanda II masih menghantui Bengkulu. Oleh sebab pada 5 Januari 1949 terjadi pertempuran antara pimpinan Batalyon XXVI yang dipimpin Nawawi Manaf melawan Belanda di Kota
Bengkulu. Perlawanan meluas sampai berbagai daerah. Selanjutnya, pasca pemindahan kekuasaan Belanda ke Indonesia, perjuangan Nawawi Manaf juga tidak mudah. Berjuang melawan masyarakat Bengkulu yang masih banyak mendukung Jepang, atas ketidakpercayaan terhadap kemerdekaan Indoensia.

Selain itu, harus menghadapi agresi militer Belanda. Pasca Agresi Belanda II berakhir, perjuangan pun belum selesai. Mereka melakukan aksi pemberontakan PRRI Sumatera Selatan. Tujuannya hanya mendorong otonomi daerah. Bahwa pembangunan harus merata sampai Sumatera, bukan dipusatkan di pulau Jawa.

\section{Saran}

Tulisan ini dapat memberikan nilainilai-nilai teladan dari Letnan Satu Nawawi Manaf untuk generasi muda. Harapannya juga dapat diperjuangkan untuk dapat dijadikan sebagai pahlawan nasional. Untuk generasi sekarang, bisa memberikan motivasi dalam melakukan penelitian yang bertema peranan tokoh sejarah lokal. Sehingga jejak-jejak sejarahnya tidak punah, khusus pahlawan lokal. Pada dunia pendidikan terutama sekolah dan Perguruan Tinggi dapat memasukkan konteks sejarah lokal masing-masing. Supaya peserta didik dapat mengetahui sejarah daerahnya sendiri sebelum belajar sejarah bangsa lain. Bagi pemerintah juga bisa ikut berperan dalam penelitian 
sejarah, sehingga pemerhati sejarah dapat mengembangkan prestasinya terutama dalam bidang karya ilmiah.

\section{Daftar Pustaka}

Alian. (2005). Metode Sejarah dan Implementasi dalam Penelitian. Universitas Sriwijaya. Palembang.

Imanuel C Florentinus. (2015). Budaya Sungai Bawang Kecamatan Muara Badak Kab . Kutai Kartanegara.EJournal.Ip.Fisip-Unmul, 1-2.

Irwanto, Dedi. 2014. Metodelogi dan Historiografi Sejarah. Yogyakarta : Eja_Publisher.

Purwanti, Retno. 2013. Keadaan Lingkungan Provindi Bengkulu dalam Peradaban di Pantai Barat Sumatera. Palembang: Ombak.

Ranni, M.Z. 1990. Perlawanan Terhadap Penjajahan dan Perjuangan Menegakkan Kemerdekaan Indonesai di Bumi Bengkulu. Balai Pustaka:Jakarta.

Stamadova, H. (2017). Peranan Tokoh Adat Dalam Mempertahankan Adat Tunggu Tubang Pada Masyarakat Semendo Di Desa Sinar Semendo Kelurahan Labuhan Dalam Kecamatan Tanjung Senang Kota Bandar Lampung. Universitas Lampung. Lampung.

Suryana. (2012). Metodologi Penelitian: Metodologi Penelitian Model Prakatis Penelitian Kuantitatif dan Kualitatif.Universitas Pendidikan Indonesia, 1-243.

Susanti, L. Joebagio, H. \& Yamtinah, S. (2018). Tradisi Tunggul Wulung Sebagai Sarana Penguat Jati Diri Bangsa. Agastya: Jurnal Sejarah Dan Pembelajarannya, 8(01), 49-58. doi: http://doi.org/10.25273/ajsp.v $8 \mathrm{i} 01.1893$

Tim Penyusun Sejarah Perjuangan SUBKOSS. 2003. Sejarah dan Peranan SUBKOSS dalam Perjuangan Rakyat Sumbagsel
(1945-1950). Provinsi Sumatra Selatan: Dewan Harian Daerah Badan Penggerak Pembudayaan Jiwa, semangat dan Nilai-Nilai Kejuangan 1945.

Tim Peneliti Nawawi Manaf dalam Perjuangan Kemerdekaan di Bengkulu. 2003. Nawawi Manaf dalam Perjuangan Kemerdekaan di Bengkulu. Padang : Balai Kajian Sejarah dan Nilai Tradisional Padang.

Tim Peneliti Sejarah Revolusi Kemerdekaan (1945-1949) Daerah Bengkulu. 1979/1980. Sejarah Revolusi Kemerdekaan (1945-1949) Daerah Bengkulu. Bengkulu : Pusat Peneliti Sejarah dan Budaya Daerah Proyek Inventarisasi dan Dokumentasi Kebudayaan Daerah. 